\title{
PENGEMBANGAN MULTIMEDIA PEMBELAJARAN INTERAKTIF UNTUK BELAJAR MEMBACA AL-QURAN METODE QIRA'ATI DI TPQ RAUDLOTUT THALIBIN
}

\author{
Habib Hambali, Herman Dwi Surjono \\ Universitas Negeri Yogyakarta, Universitas Negeri Yogyakarta \\ habib_uny@yahoo.co.id, hermansurjono@uny.ac.id
}

\begin{abstract}
Abstrak
Penelitian ini bertujuan untuk menghasilkan program multimedia pembelajaran interaktif untuk memudahkan dan menumbuhkan minat santri dalam belajar membaca AlQuran metode qira'ati yang layak digunakan dalam proses pembelajaran ditinjau dari aspek isi, aspek pembelajaran, aspek tampilan dan aspek pemrograman. Penelitian ini merupakan penelitian dan pengembangan yang mencakup sembilan langkah kegiatan, yaitu: mengumpulkan informasi dan penelitian pendahuluan, perencanaan, pengembangan produk awal, uji coba lapangan awal, revisi produk uji coba lapangan awal, uji coba lapangan utama, revisi produk uji coba lapangan utama, uji coba lapangan operasional, revisi produk ujicoba lapangan operasional, dan produk akhir. Hasil penelitian adalah sebagai berikut: (1) produk yang dihasilkan adalah program multimedia pembelajaran interaktif belajar membaca AlQuran metode qira'ati yang dikemas dalam bentuk CD; dan (2) progam multimedia pembelajaran interaktif belajar membaca Al-Quran metode qira'ati ini efektif digunakan untuk pembelajaran membaca Al-Quran. Hal ini ditunjukkan dari hasil analisis kartu prestasi sebelum dan sesudah menggunakan program multimedia.
\end{abstract}

Kata kunci: program multimedia, pembelajaran, Al-Quran

\section{DEVELOPING AN INTERACTIVE MULTIMEDIA PROGRAM FOR LEARNING TO READ QURAN THROUGH QIRA'ATI METHOD AT TPQ RAUDLOTUT THALIBIN}

Habib Hambali, Herman Dwi Surjono

Universitas Negeri Yogyakarta, Universitas Negeri Yogyakarta habib_uny@yahoo.co.id, hermansurjono@uny.ac.id

\begin{abstract}
This study aims to produce an interactive teaching multimedia program to facilitate and grow students' interest in learning to read the Al-Qur'an using the qira'ati method which can be used properly in learning process viewed from content, teaching, display, and programming aspects. This study was a research and development which included nine steps, i.e.: collecting information and preliminary study, planning, initial product development, initial field testing, revision of initial field testing products, primary field testing, revision of primary field testing product, operational field testing, revision of operational field testing product, final product. The results of the study are as follows: (1) The developed product is an interactive teaching multimedia program for learning reading Quran through qira'ati method in a $C D$, (2) This interactive teaching multimedia program reading is effective for learning to read Al-Qur'an.
\end{abstract}

Keywords: multimedia program, learning, Al-Qur'an 


\section{Pendahuluan}

Kegiatan belajar mengajar metode qiraati di TPQ terdiri dari peserta didik yang disebut dengan santri, dan pendidik yang disebut dengan ustad. Pembelajaran di TPQ Roudlotut Tholibin Kembaran Kebumen menggunakan metode qiraati dengan menggunakan 6 jilid. Metode ini merupakan cara atau kurikulum yang digunakan dalam proses pembelajaran. Tahun 1963 metode qiraati mulai disusun oleh KH. Dachlan Salim Zarkasyi di Semarang. (Zarkasyi, 2006, p.1).

Berdasarkan hasil observasi dan wawancara di TPQ Raudlotut Thalibin pada hari Senin, 2 Desember 2013 diperoleh masalah bahwa, dalam kegiatan pembelajaran ustad mengajarkan materi menggunakan buku panduan qiraati dan alat peraga (gambar). Akan tetapi, santri mengaku belum cukup untuk memahami materi yang disajikan sehingga masih mengalami kesulitan dalam belajar membaca Al-Quran, karena seharusnya untuk mempelajari Al-Quran dibutuhkan berbagai media penunjang yang digunakan menjelaskan materi. Ustad dalam membuat santri aktif juga memberikan motivasi dengan menggunakan kartu prestasi, tetapi kartu prestasi tersebut ternyata belum mempengaruhi santri untuk lebih aktif dan termotivasi dalam pembelajaran di kelas. Selain itu, kondisi ustad di TPQ Raudlotut Thalibin sangatlah terbatas jumlahnya, padahal pada pembelajaran Al-Quran metode qiraati idealnya seorang ustad hanya boleh mengajar kepada maksimal 20 santri, sehingga hal tersebut mengakibatkan kurangnya efektifitas ustad dalam mengajar.

Pembelajaran Al-Quran metode qiraati belum memungkinkan penggunaan media selain buku pedoman, alat peraga dan penjelasan ustad secara langsung. Hal ini terbukti bahwa dipasaran sulit didapatkan karena belum tersedia media elektronik pembelajaran Al-Quran metode qiraati. Dengan demikian ustad juga belum menggunakan media yang lain selain buku dan alat peraga sebagai sarana media pembelajaran.
Proses kegiatan pembelajarannya ustad mengajarkan materi menggunakan buku panduan qiraati dan alat peraga berupa gambar saja tanpa menggunakan media lain. Oleh sebab itu, dalam penelitian pengembangan ini memiliki tujuan untuk menciptakan sebuah program multimedia pembelajaran interaktif baru yang layak menurut ahli dan dapat dimanfaatkan oleh ustad maupun santri sebagai media penunjang kegiatan belajar mengajar Al-Quran.

\section{Metode Penelitian}

Penelitian yang akan dilakukan termasuk dalam model penelitian dan pengembangan, yaitu suatu proses yang digunakan untuk mengembangkan dan memvalidasi produk-produk yang digunakan dalam pendidikan. Waktu penelitian dilakukan pada bulan Desember 2013 hingga bulan Februari 2014 yang bertempat di TPQ Raudlotut Thalibin Kembaran, Kebumen, Jawa Tengah. Adapun tujuan dari pengembangan program ini adalah untuk memfasilitasi peserta didik/ santri saat belajar membaca Al-Quran dengan multimedia pembelajaran membaca Al-Quran.

Target atau sasaran pengguna program ini adalah untuk siswa/santri di Taman Pendidikan Al-Quran pada khususnya dan untuk semua peserta didik yang belum bisa membaca Al-Quran pada umumnya.

Gambar 1 merupakan alur prosedur pengembangannya.

Penelitian Awal dan Pengumpulan Informasi

Penelitian awal dan pengumpulan informasi dilakukan untuk mengetahui seberapa penting suatu produk multimedia pembelajaran yang akan dikembangkan. Pengumpulan informasi ini dilakukan dengan observasi, wawancara dengan ustad maupun santri di TPQ Raudlotut Thalibin Kembaran Kebumen Kebumen. Peneliti menganalisis permasalahan-permasalahan 
apa saja yang sering terjadi di TPQ, tindakan apa yang sudah dilakukan untuk mengatasi permasalahan serta apa yang menjadi kendalanya. Dari hasil analisis tersebut dapat diketahui seberapa penting diperlukannya suatu media untuk membantu mengatasi permasalahan yang terjadi.

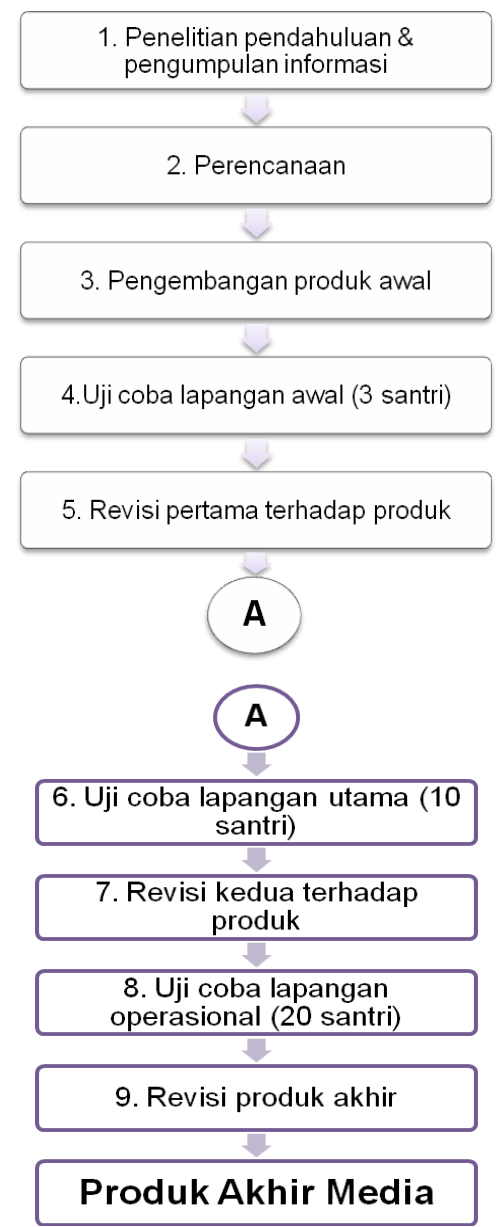

Gambar 1. Prosedur Pengembangan

Perencanaan

Setelah melakukan penelitian pendahuluan dan pengumpulan informasi, ditemukan beberapa permasalahan. Oleh karena itu, peneliti melakukan perencanaan dengan analisis pembelajaran dan menganalisis produk atau media pembelajaran yang akan dihasilkan untuk memecahkan masalah tersebut sesuai dengan data-data yang terkumpul. Analisis pembelajaran tahap ini didasarkan metodologi pengajaran Al-Quran yaitu metode qiraati di TPQ Raudlotut Thalibin Kembaran ke- camatan Kebumen kabupaten Kebumen Jawa Tengah.

Untuk mencapai indikator keberhasilan tersebut, diperlukan media untuk memudahkan santri dalam belajar membaca Al-Quran. Program multimedia pembelajaran interaktif untuk belajar membaca Al-Quran di TPQ metode qiraati adalah media yang dapat membantu santri dalam belajar membaca Al-Quran. Oleh karena itu, program multimedia pembelajaran interaktif untuk belajar membaca Al-Quran metode qiraati ini perlu dikembangkan.

\section{Mengembangkan Produk Awal}

Pada tahap ini dilakukan dengan mengembangkan media, instrumen evaluasi dan meminta pertimbangan ahli (Expert Judgement), yaitu 2 orang ahli materi dan 2 orang ahli media. Ahli materi memberikan penilaian terhadap aspek pembelajaran dan isi materi, sedangkan ahli media memberikan penilaian terhadap aspek kemediaan.

Berdasarkan validasi ahli, data yang masuk digunakan untuk mencari apakah masih ada ketidaksesuaian atau kesalahan pada program multimedia pembelajaran interaktif untuk belajar membaca Al-Quran, kemudian peneliti merevisi media tersebut sesuai dengan catatan dan masukan dari validasi ahli. Hasil dari revisi ini kemudian diuji cobakan kembali kepada pengguna dalam skala kecil yaitu uji lapangan awal.

\section{Uji Coba Lapangan Awal}

Uji coba lapangan awal dimaksudkan untuk memperoleh informasi maupun koreksi setelah penggunaan produk yang telah dihasilkan. Uji coba ini melibatkan 3 santri di TPQ Raudlotut Thalibin Kembaran Kebumen, yang memiliki kemampuan diantaranya di atas rata-rata dan di bawah rata-rata. Beri kesempatan santri tersebut untuk menggunakan program multimedia pembelajaran interaktif untuk belajar membaca Al-Quran metode qiraati, yang telah direvisi dari hasil validitas ahli materi dan 
ahli media. Untuk mendapat masukan sebagai bahan revisi, maka diperlukan pengamatan saat santri menggunakan media pembelajaran tersebut, dan pemberian angket sebagai bahan analisis untuk revisi produk.

\section{Revisi Produk Utama}

Berdasarkan hasil uji lapangan awal, data yang masuk dianalisis terlebih dahulu, sehingga diperoleh suatu kesimpulan apa saja yang diperlukan untuk merevisi produk tersebut. Masukan maupun saran yang diperoleh selama uji lapangan awal digunakan sebagai acuan dalam merevisi produk tersebut, sehingga menghasilkan produk baru yang telah direvisi berdasarkan data yang diperoleh dalam uji coba sebelumnya. Hasil revisi produk awal kemudian digunakan dalam uji lapangan utama.

\section{Uji Coba Lapangan Utama}

Uji coba ini dimaksudkan untuk memperoleh informasi maupun koreksi dari pemanfaatan produk yang telah direvisi setelah uji coba lapangan awal. Uji coba lapangan utama melibatkan 10 santri di TPQ Raudlotut Thalibin Kembaran Kebumen, yang memiliki karakteristik berbeda-beda mulai dari laki-laki, perempuan, pandai, sedang, dan kurang pandai. Beri kesempatan santri tersebut untuk menggunakan program multimedia pembelajaran interaktif untuk belajar membaca AlQuran metode qiraati, yang telah direvisi dari hasil uji coba lapangan awal dan melakukan pengamatan terhadap kegiatan santri. Kemudian santri diwawancarai dengan pertanyaan ringan untuk mengevaluasi media yang telah digunakan sebelumnya. Hasil pengamatan dan wawancara yang terkumpul sebagai bahan acuan revisi program multimedia pembelajaran selanjutnya.

\section{Revisi Produk Operasional}

Berdasarkan uji coba lapangan utama dan setelah menganalisis data yang diperoleh, peneliti akan melakukan revisi produk apabila masih diketahui kekurangan dalam program multimedia pembelajaran interaktif untuk belajar membaca AlQuran tersebut dan perlu untuk direvisi. Acuan yang digunakan untuk mengetahui adanya kekurangan dan perlu adanya revisi adalah berdasarkan data yang diperoleh pada hasil pengamatan dan jawaban pertanyaan wawancara yang diberikan kepada santri pada uji coba sebelumnya, yaitu uji coba lapangan utama sehingga diperoleh masukan yang dapat dijadikan dasar dalam merevisi kembali produk tersebut. Selanjutnya setelah direvisi berdasarkan data dari uji coba lapangan utama maka produk tersebut akan dijadikan bahan dalam uji coba lapangan operasional.

\section{Uji Coba Lapangan Operasional}

Uji coba lapangan operasional dilakukan kepada 1 kelas atau 20 santri di TPQ Raudlotut Thalibin Kembaran Kebumen. Program multimedia pembelajaran interaktif untuk belajar membaca Al-Quran yang digunakan santri, kemudian diadakan pengamatan dan wawancara kepada para santri setelah menggunakan media tersebut, Hal ini dimaksudkan untuk memperoleh masukan-masukan maupun koreksi tentang program multimedia pembelajaran interaktif untuk belajar membaca Al-Quran yang telah direvisi setelah uji coba lapangan awal dan uji coba lapangan utama. Hasil dari uji coba ini nantinya dijadikan pijakan dalam melakukan revisi produk selanjutnya.

\section{Revisi Produk Akhir}

Data dari hasil uji coba lapangan operasional akan dijadikan sebagai bahan pijakan dalam melakukan revisi akhir program dan merupakan hasil akhir dalam pengembangan program multimedia pembelajaran interaktif untuk belajar membaca Al-Quran.

Mendesiminasikan dan Mengimplementasikan Produk

Setelah pada tahap akhir revisi produk kemudian langkah selanjutnya adalah 
mendesiminasikan dan mengimplementasikan produk. Karena adanya keterbatasan peneliti dalam melakukan penelitian maka pada tahap ini peneliti hanya membuat produk akhir dari multimedia pembelajaran yang sudah tidak ada revisi lagi, sehingga produk akhir yang dihasilkan berupa program multimedia pembelajaran interaktif untuk belajar membaca Al-Quran telah teruji validasinya dan dapat dikatakan layak sebagai media pembelajaran.

Jenis data pada penelitian ini adalah data kualitatif dan data kuantitatif. Data kualitatif diperoleh dari hasil observasi dan wawancara, sedangkan data kuantitatif didapatkan dari ahli media, ahli materi dan santri. Data tersebut dimaksudkan untuk melihat kualitas masing-masing pengembangan program multimedia pembelajaran, agar nantinya dapat digunakan dalam proses pembelajaran.

Teknik dan Instrumen Pengumpul Data

Observasi

Observasi dalam penelitian pengembangan ini dilakukan pada saat penelitian pendahuluan (prasurvey), yaitu pengumpulan informasi tentang kondisi, sarana dan pra sarana pembelajaran

\section{Wawancara}

Kegiatan ini dilakukan untuk mendapatkan data secara mendalam tentang kualitas produk pengembangan program yang telah dikembangkan

Angket

Angket digunakan untuk mengetahui ketepatan rancangan produk sebagai program multimedia pembelajaran dari ahli materi, ahli media dan santri.

Langkah-langkah dalam analisis data antara lain: (a) mengumpulkan data mentah; (b) pemberian skor; (c) skor yang diperoleh kemudian dikonversikan menjadi nilai dengan skala 5 menggunakan acuan konversi dari Sukardi (2008, p.179) yang disajikan pad Tabel 1.
Tabel 1. Konversi Nilai

\begin{tabular}{ccc}
\hline Nilai & Kriteria & Skor \\
\hline A & Sangat Baik & $\mathrm{X}>4,21$ \\
B & Baik & $3,40<\mathrm{X} \leq 4,21$ \\
C & Cukup & $2,6<\mathrm{X} \leq 3,40$ \\
D & Kurang & $1,79<\mathrm{X} \leq 2,60$ \\
E & Sangat kurang & $\mathrm{X} \leq 1,79$ \\
\hline
\end{tabular}

Untuk mencari skor rata-rata (rerata skor) digunakan rumus berikut.

$$
\overline{X \imath}=\frac{\sum X}{n}
$$

\section{Hasil Penelitian dan Pembahasan}

Pengembangan program multimedia pembelajaran interaktif untuk belajar membaca Al-Quran metode qiraati di taman pendidikan Al-Quran Raudlotut Thalibin Kembaran Kebumen ini dikembangkan melalui penelitian pendahuluan. Penelitian pendahuluan dilakukan melalui studi pustaka dan studi lapangan untuk menganalisis kebutuhan yang diperlukan untuk kepeluan pengembangan yang berdasarkan atas temuan fakta yang diperoleh dari observasi, wawancara dengan ustad dan analisis kepustakaan. Penelitian ini diawali dengan penelitian pendahuluan yang dilakukan pada bulan Oktober-November 2013 di Taman Pendidikan Al-Quran Metode Qiraati Raudlotut Thalibin Kembaran Kebumen Jawa Tengah.

Data yang diperoleh selama melakukan studi pustaka di Taman Pendidikan Al-Quran metode qiraati Raudlotut Thalibin Kembaran Kebumen Jawa Tengah dapat diketahui bahwa: (1) standar kompetensi dalam pembelajaran Al-Quran metode qiraati adalah santri dapat membaca Al-Quran dengan lancar dan benar sesuai makhrojul hurufnya. (2) media yang digunakan santri untuk pembelajaran Al-Quran berupa alat peraga, sedangkan bahan ajar yang digunakan santri untuk pembelajaran Al-Quran adalah buku Qiraati yang ditebitkan dari Semarang oleh Bpk. KH. Dachlan Salim Zarkasyi (pendiri metode 
qiraati), (3) bahan ajar yang digunakan siswa kurang menarik karena masih terlalu naratif.

Beberapa data yang diperoleh berdasarkan data studi lapangan melaui observasi dan wawancara, disimpulkan bahwa: (1) Taman Pendidikan Al-Quran metode qiraati Raudlotut Thalibin Kembaran Kebumen sudah memiliki laboratorium komputer yang layak digunakan untuk pembelajaran hanya saja jumlah komputer tidak sebanding dengan jumlah santri. Akan tetapi santri sudah banyak yang memiliki komputer/laptop pribadi dirumahnya, sehingga permasalahan tersebut tidak menjadi hambatan untuk memanfaatkan suatu program multimedia pembelajaran; (2) program multimedia pembelajaran interaktif untuk belajar membaca Al-Quran metode qiraati di TPQ tersebut belum pernah dikembangkan untuk proses pembelajaran; (3) Media yang ada di TPQ tersebut hanyalah papan tulis dan alat peraga saja belum mengembangkan media dengan program multimedia pembelajaran; dan (4) materi pembelajaran membaca Al-Qur-an yang dibahas sangat padat, sedangkan ustad mengajar hanya dengan menggunakan waktu yang sedikit (singkat) dan media yang sangat sederhana dan terbatas.

\section{Deskripsi dan Analisis Data Validasi Ahli}

\section{Deskripsi Data Validasi Ahli Materi}

Validasi ahli materi tahap 1 dilaksanakan pada tanggal 9 Februari 2014 dengan hasil aspek pembelajaran 4,29 (sangat baik), Aspek isi 4,46 (sangat baik), rata-rata skor 4,37 (sangat baik) dan tahap kedua dilaksanakan pada tanggal 11 Februari 2014 dengan hasil aspek pembelajaran 4,47 (sangat baik), Aspek isi 4,6 (sangat baik), rata-rata skor 4,53 (sangat baik).

\section{Deskripsi Data Validasi Ahli Media}

Validasi ahli media dilakukan pada tanggal 3 Februari 2014 dengan hasil aspek tampilan 4,5 (sangat baik), aspek Pem- rograman 4,73, rata-rata skor 4,61 (sangat baik).

Deskripsi dan Analisis Data Uji Coba Lapangan

\section{Deskripsi Data Uji Coba Lapangan Awal}

Uji coba lapangan awal dilaksanakan pada tanggal 15 Februari 2014 dengan hasil jumlah skor 150 dan rata-rata 5 (sangat baik).

\section{Deskripsi Data Uji Coba Lapangan Utama}

Uji coba lapangan utama dilaksanakan pada tanggal 19 Februari 2014 dengan hasil jumlah skor 456 dan rata-rata 4,56 (sangat baik).

\section{Deskripsi Data Uji Coba Lapangan Operasional}

Uji coba lapangan operasional dilaksanakan pada tanggal 24 Februari 2014 dengan hasil jumlah skor 952 dan rata-rata 4,84 (sangat baik).

\section{Deskripsi Hasil Belajar Santri}

Krinteria penilaian:

LB/B : nilai antara 75-100

LMB/C : nilai antara 55-74

LMMB/D : nilai antara 0-54

Krieria Ketuntasan Minimal: 75

Deskripsi rerata hasil belajar santri sebelum menggunakan program, hari pertama 61,4, hari kedua 66,95, hari ketiga 60,2 , hari keempat 62,65 , dan rerata nilai keseluruhan 62,8 . Berikut ini secara rinci ditampilkan deskripsi dari hasil belajar santri sebelum menggunakan media sebagaimana disajikan pada Tabel 2 .

Deskripsi hasil belajar santri sesudah menggunakan program, hari pertama 73,6, hari kedua 76,4, hari ketiga 85,45 , hari keempat 85,35 , dan rerata nilai keseluruan 80,2 . Berikut ini secara rinci ditampilkan deskripsi dari hasil belajar santri sebelum menggunakan media sebagaimana disajikan dalam Tabel 3 . 
Tabel 2. Diskrisi Hasil Belajar Santri Sebelum Menggunakan Media

\begin{tabular}{|c|c|c|c|c|c|c|c|c|}
\hline \multirow{2}{*}{ No } & \multirow{2}{*}{ Santri } & \multicolumn{4}{|c|}{ Nilai Hari Ke } & \multirow{2}{*}{$\begin{array}{c}\text { Rerata } \\
\text { Nilai }\end{array}$} & \multirow{2}{*}{ Simbol } & \multirow{2}{*}{ Keterangan } \\
\hline & & I & II & III & VI & & & \\
\hline 1 & Santri 1 & 40 & 45 & 42 & 53 & 45 & LMMB & U (Ulang) \\
\hline 2 & Santri 2 & 55 & 50 & 51 & 66 & 55,5 & LMB & U (Ulang) \\
\hline 3 & Santri 3 & 80 & 76 & 79 & 80 & 78,75 & LB & L (Lanjut) \\
\hline 4 & Santri 4 & 77 & 86 & 75 & 71 & 77,25 & LB & L (Lanjut) \\
\hline 5 & Santri 5 & 67 & 52 & 63 & 68 & 62,5 & LMB & U (Ulang) \\
\hline 6 & Santri 6 & 57 & 60 & 70 & 85 & 68 & LMB & U (Ulang) \\
\hline 7 & Santri 7 & 52 & 52 & 54 & 60 & 54,5 & LMMB & U (Ulang) \\
\hline 8 & Santri 8 & 58 & 61 & 70 & 66 & 62,25 & LMB & U (Ulang) \\
\hline 9 & Santri 9 & 63 & 60 & 55 & 61 & 59,75 & LMB & U (Ulang) \\
\hline 10 & Santri 10 & 73 & 75 & 80 & 85 & 78,25 & LB & L (Lanjut) \\
\hline 11 & Santri 11 & 79 & 70 & 68 & 50 & 66,75 & LMB & U (Ulang) \\
\hline 12 & Santri 12 & 77 & 68 & 60 & 73 & 69,5 & LMB & U (Ulang) \\
\hline 13 & Santri 13 & 80 & 75 & 60 & 55 & 67,5 & LMB & U (Ulang) \\
\hline 14 & Santri 14 & 62 & 61 & 71 & 77 & 67,75 & LMB & U (Ulang) \\
\hline 15 & Santri 15 & 41 & 55 & 50 & 64 & 52,5 & LMMB & U (Ulang) \\
\hline 16 & Santri 16 & 74 & 70 & 63 & 75 & 70,5 & LMB & U (Ulang) \\
\hline 17 & Santri 17 & 42 & 50 & 35 & 64 & 47,75 & LMMB & U (Ulang) \\
\hline 18 & Santri 18 & 66 & 70 & 53 & 55 & 61 & LMB & U (Ulang) \\
\hline 19 & Santri 19 & 50 & 50 & 62 & 45 & 51,75 & LMMB & U (Ulang) \\
\hline \multirow[t]{2}{*}{20} & Santri 20 & 35 & 40 & 43 & 56 & 43,5 & LMMB & U (Ulang) \\
\hline & Rerata & 61,4 & 66,95 & 60,2 & 62,65 & 62,8 & & \\
\hline
\end{tabular}

Tabel 3. Diskripsi Hasil Belajar Santri sesudah Menggunakan Media

\begin{tabular}{|c|c|c|c|c|c|c|c|c|}
\hline \multirow{2}{*}{ No } & \multirow{2}{*}{ Santri } & \multicolumn{4}{|c|}{ Nilai Hari Ke } & \multirow{2}{*}{$\begin{array}{c}\text { Rerata } \\
\text { Nilai }\end{array}$} & \multirow{2}{*}{ Simbol } & \multirow{2}{*}{ Keterangar } \\
\hline & & I & II & III & VI & & & \\
\hline 1 & Santri 1 & 70 & 75 & 82 & 83 & 77,5 & LB & L (Lanjut) \\
\hline 2 & Santri 2 & 80 & 65 & 71 & 76 & 73 & LMB & U (Ulang) \\
\hline 3 & Santri 3 & 80 & 76 & 89 & 95 & 85 & LB & L (Lanjut) \\
\hline 4 & Santri 4 & 77 & 76 & 85 & 91 & 82,25 & LB & L (Lanjut) \\
\hline 5 & Santri 5 & 67 & 82 & 73 & 78 & 75 & LB & L (Lanjut) \\
\hline 6 & Santri 6 & 77 & 80 & 85 & 95 & 84,25 & LB & L (Lanjut) \\
\hline 7 & Santri 7 & 72 & 82 & 94 & 90 & 84,5 & LB & L (Lanjut) \\
\hline 8 & Santri 8 & 78 & 81 & 90 & 86 & 83,75 & LB & L (Lanjut) \\
\hline 9 & Santri 9 & 73 & 80 & 75 & 91 & 79,75 & LB & L (Lanjut) \\
\hline 10 & Santri 10 & 77 & 85 & 90 & 94 & 86,5 & LB & L (Lanjut \\
\hline 11 & Santri 11 & 79 & 75 & 80 & 80 & 78,5 & LB & L (Lanjut) \\
\hline 12 & Santri 12 & 77 & 78 & 80 & 83 & 79,5 & LB & L (Lanjut) \\
\hline 13 & Santri 13 & 70 & 75 & 60 & 78 & 70,75 & LMB & U (Ulang) \\
\hline 14 & Santri 14 & 70 & 71 & 81 & 87 & 77,25 & LB & L (Lanjut) \\
\hline 15 & Santri 15 & 68 & 75 & 74 & 76 & 73,25 & LMB & U (Ulang) \\
\hline 16 & Santri 16 & 74 & 77 & 76 & 85 & 78 & LB & L (Lanjut) \\
\hline 17 & Santri 17 & 70 & 78 & 85 & 88 & 80,25 & LB & L (Lanjut) \\
\hline 18 & Santri 18 & 68 & 70 & 73 & 80 & 72,75 & LMB & U (Ulang) \\
\hline 19 & Santri 19 & 70 & 77 & 82 & 85 & 78,5 & LB & L (Lanjut) \\
\hline 20 & Santri 20 & 75 & 70 & 83 & 86 & 78,5 & LB & L (Lanjut) \\
\hline & Rerata & 73,6 & 76,4 & 85,45 & 85,35 & 80,2 & & \\
\hline
\end{tabular}


Bentuk akhir dari produk yang dikembangkan adalah program multimedia pembelajaran Al-Quran metode qiraati yang memuat materi "pengenalan huruf hijaiyah sampai dengan bacaan Al-Quran dilengkapi dengan hafalan do'a harian dan surat pendek". Dan dikemas kedalam CD (Compact Disc).

Program ini ditujukan untuk santri TPQ yang terdiri dari 6 level/bagian utama untuk belajar membaca Al-Quran dan didalamnya sudah dilengkapi dengan teks, audio dan video pembelajarannya. Adapun komponen dari program ini terdiri dari: cover, kata pengantar, petunjuk penggunaan, SKKD, profil pengembang, materi dan evaluasi. Berikut ditampilkan hasil dari program pengembangan multimedia pembelajaran Al-Quran metode qiraati yang sudah dikembangkan sebagaimana disajikan pada Gambar 2 dan Gambar 3.

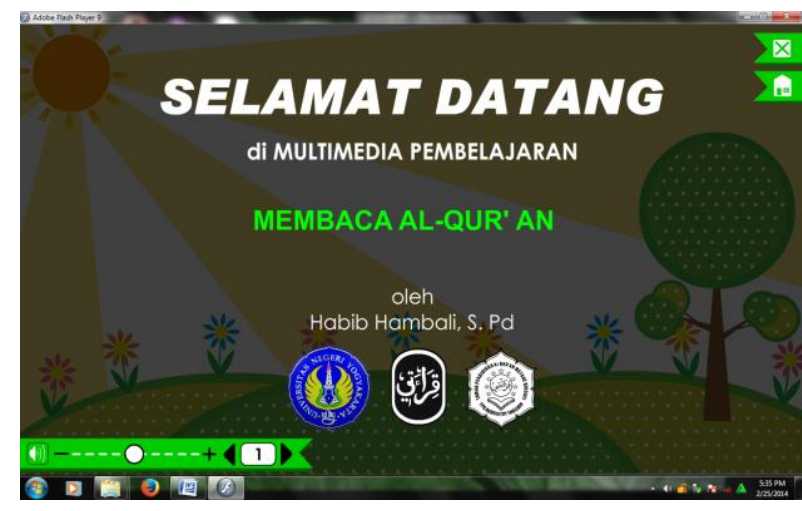

Gambar 2. Tampilan Awal Program Multimedia Pembelajaran Al-Quran

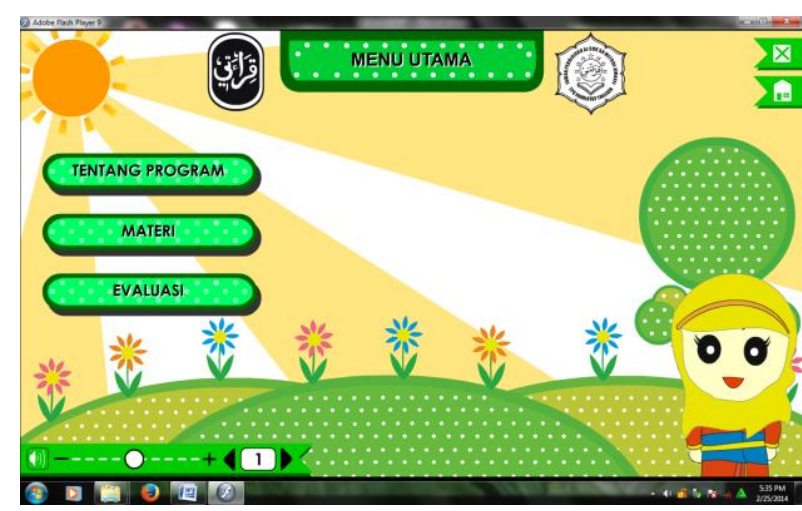

Gambar 3. Tampilan Isi Program Multimedia Pembelajaran Al-Quran

\section{Simpulan dan Saran}

\section{Simpulan}

Berdasarkan pada hasil penelitian dan pengembangan program multimedia pembelajaran Al-Quran metode qiraati ini, dapat disimpulkan bahwa: (1) produk dari penelitian dan pengembangan yang dilakukan adalah program multimedia berbentuk CD yang digunakan untuk menjelaskan materi pembelajaran membaca AlQuran metode qiraati; (2) produk ini layak digunakan dalam pembelajaran berdasarkan penilaian dari ahli materi dan ahli media yang ditinjau dari aspek pembelajaran, aspek isi, aspek tampilan dan aspek pemrograman dengan rerata skor 4,50 dengan kategori Sangat Baik dan rerata skor dari keseluruhan uji coba lapangan sebesar 4,80 dengan kategori Sangat Baik; (3) dan program multimedia hasil pengembangan ini dalam penggunaannya sangatlah bermanfaat bagi ustad maupun santri dalam proses kegiatan belajar mengajar

\section{Saran}

\section{Saran Pemanfaatan bagi Ustad}

Hendaknya menjelaskan terlebih dahulu kepada santri tentang program, cara kerja program, dan juga cara penggunaannya

Dalam proses pembelajaran ustad dapat menyampaikan materi menggunakan program multimedia pembelajaran AlQuran metode qiraati ini dengan cara menjelaskan dan mengajak diskusi kepada santri.

\section{Saran Pemanfaatan bagi Santri}

Santri hendaknya membaca dan mempelajari keseluruhan materi dalam bahan ajar ini dengan baik secara berurutan sesuai dengan tingkatan level/jilidnya.

Santri hendaknya berlatih untuk terbiasa dan sering mengoperasionalkan program. 
Diseminasi

Penyebarluasan program ini dapat melalui koordinasi langsung dengan kordinator kecamatan (KorCam), kordinator cabang (KorCab) ataupun kordinator wilayah (KorWil). Sedangkan diseminasi produk dapat melalui Silacab (Silaturahmi Cabang) dan dapat juga disampaikan melalui seminar-seminar yang relevan

Pengembangan Produk Lebih Lanjut

Untuk hasil yang lebih maksimal pada pengembangan program lebih lanjut supaya dapat menambahkan kelengkapan komponen yang belum tersedia seperti cara membaca Al-Quran dengan Lagu (murrotal), selain itu juga dapat menambahkan video dengan tampilan 3D atau pembelajaran membaca Al-Quran dengan bantuan animasi (teks).

\section{Daftar Pustaka}

Borg, W.R. \& Gall, M.D. (1983). Educational research. An introduction. New York: Longman.

Sukardi. (2008). Evaluasi pendidikan: prinsip dan operasionalnya. Jakarta: Bumi Aksara.

Tujiyo. (2007). Pengembangan multimedia pembelajaran matematika di SMA. Tesis magister, tidak diterbitkan. Universitas Negeri Yogyakarta. Yogyakarta.

Zarkasyi, D. (2006). Panduan belajar membaca al-quran, hafalan surat pendek, do'a harian, dan fasholatan metode qiraati. Kebumen: AL-Mukarromah. 